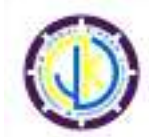

e-ISSN: 2580-6947

p-ISSN: 2354-7278

http://ojs.umrah.ac.id/index.php/kiprah/index

\title{
PENDEKATAN ALTERNATIF SEBAGAI STRATEGI EVALUASI PROGRAM PELATIHAN DAUR ULANG SAMPAH ORGANIK DENGAN METODE TAKAKURA
}

\author{
M. Syahruddin Amin ${ }^{1^{*}}$ \\ ${ }^{1}$ Universitas Hamzanwadi, Kab. Lombok Timur, Nusa Tenggara Barat 83611, Indonesia
}

\begin{abstract}
Keberadaan sampah saat ini telah menjadi permasalahan bagi kehidupan dan lingkungan. Daur ulang sampah, sosialisasi, dan pelatihannya terus gencar dilakukan termasuk melalui institusi pendidikan melalui sekolah adiwiyata. Program sosialisasi dan pelatihan daur ulang sampah organik dengan metode Takakura dilakukan untuk mendukung upaya daur ulang sampah secara mandiri disekolah. Evaluasi program berfungsi untuk menyediakan informasi tentang kinerja seluruh komponen program dalam setiap tahap prosesnya. Studi kualitatif library research ini berupaya menemukan strategi evaluasi yang tepat untuk program sosialisasi dan pelatihan daur ulang sampah dengan metode Takakura. Dari studi pustaka (buku, literatur, maupun artikel) yang dilakukan, penulis mengkonstruksi sebuah strategi evaluasi program yang sesuai dengan karakteristik program sosialisasi dan pelatihan daur ulang sampah organik dengan metode Takakura. Evaluasi ini menggunakan pendekatan alternatif dengan mengkombinasi decision-oriented approach dan program-oriented approach. Bentuk praktis kombinasi tersebut ialah strategi evaluasi yang memadukan dua model yaitu goal-oriented model (Tyler) dan CSE-UCLA model (Alkins). Kerangka evaluasi mencakup tiga tahap program yaitu program planning, program implementation, program improvement. Proses evaluasi berlangsung dalam beberapa tahap yaitu define objectives, find situation, select and develop measurement technique, dan collect performance data (Tyler). Pengambilan data dalam evaluasi program ini dilakukan menggunakan beberapa instrumen yaitu angket, pedoman wawancara, lembar observasi, check list, dan tes. Data evaluasi dianalisis menggunakan teknik analisis kualitatif dan kuantitatif (deskriptif).
\end{abstract}

Kata Kunci: program daur ulang sampah dan metode takakura, evaluasi program, pendekatan alternatif (model Tyler dan model Alkins)

\section{PENDAHULUAN}

Permasalahan lingkungan saat ini menjadi salah satu isu sentral dalam perkembangan dunia secara global. Tingginya tingkat pencemaran lingkungan telah berdampak pada menurunnya kualitas hidup manusia. Salah satu permasalahan lingkungan tersebut ialah sampah. Jumlah sampah yang dibuang ke lingkungan tidak sebanding dengan upaya penanggulangan, pengolahan, maupun daur ulangnya. Pengelolaan sampah saat ini telah menjadi salah satu isu utama dalam konteks pelestarian lingkungan.

Secara umum, sampah diartikan sebagai bahan buangan (sisa) yang sudah tidak dipergunakan dan tidak diinginkan orang. Namun demikian jika bahan buangan ini tidak ditangani

*Penulis Korepondensi

Email Address : muhammad_syahruddinamin@yahoo.com dengan benar akan menimbulkan gangguan terhadap kesehatan masyarakat dan lingkungan. Menurut Undang-undang Nomor 18 Tahun 2008 pasal 1 ayat (1) bahwa yang dimaksud dengan sampah adalah:

"Sampah adalah sisa-sisa kegiatan sehari-hari manusia dan/atau proses alam yang berbentuk padat"

Berdasarkan komposisi kimianya, sampah dibedakan menjadi dua yaitu sampah organik, yang terdiri dari bahan-bahan penyusun tumbuhan dan hewan yang diambil dari alam atau dihasilkan dari kegiatan pertanian, perikanan, dan lain-lain. Sampah jenis ini dapat terurai dengan sangat mudah secara alami. Penelitian mengenai sampah padat di Indonesia menunjukkan bahwa $80 \%$-nya 


\section{JURNAL KIPRAH, Juni 2018; V1(1): 25-34 \\ e-ISSN: 2580-6947 \\ p-ISSN: 2354-7278}

adalah sampah organik (Outerbridge, ed.1991), hal ini sejalan dengan hasil survey di Jakarta, Bogor, Bandung, dan Surabaya (Sudradjat, 2007) yang menunjukkan bahwa jumlah sampah organik mencapai $75 \%$ - $95 \%$ dari total sampah yang ada. Kedua, sampah anorganik, yaitu jenis sampah yang berasal dari sumber daya yang tak bisa diperbaharui seperti bahan mineral dan sisa industri. Secara umum sebagian besar sampah anorganik tidak dapat diuraikan oleh alam, namun sebagian dapat diuraikan oleh alam dalam waktu yang sangat lama contohnya plastik.

Pemerintah melalui Kementerian Lingkungan Hidup dan Kehutanan menggulirkan Program Sekolah Adiwiyata yang bertujuan untuk menyebarluaskan sikap dan perilaku ramah lingkungan kepada siswa melalui institusi pendidikan. Dalam program ini tercakup beberapa aktifitas dasar diantaranya hemat energi, penghijauan, hemat air, dan daur ulang sampah. Banyak ragam proses sosialisasi dan pelatihan pengolahan sampah yang dilakukan ke sekolahsekolah. Peneliti bersama tim melakukan sosialisasi dan pelatihan daur ulang sampah, dalam hal ini dengan Metode Takakura, guna memberikan alternatif pilihan teknik pengolahan sampah secara mandiri di lingkungan sekolah,. Takakura Home Composting Method merupakan satu metode pengomposan skala mikro yang menggunakan media keranjang, yang dikenal sebagai keranjang Takakura. Namun demikian hingga saat ini metode evaluasi untuk mengukur keberhasilan program tersebut belum tersedia. Oleh karena itu, artikel ini mencoba menghadirkan sebuah strategi evaluasi untuk permasalahan tersebut.

\section{Profil Program}

Program dari Science Club ini bertujuan untuk (1) memberikan pemahaman pada siswa tentang sampah dan pentingnya mengolah sampah, (2) menumbuhkan kesadaran lingkungan pada diri siswa yang terkait dengan pengolahan dan daur ulang sampah organik, (3) Memberikan pelatihan pada siswa mengenai teknik daur ulang sampah organik menjadi kompos dengan Takakura Home Composting Method. Program ini melibatkan beberapa stake holder yaitu Kaprodi dan Waka Kesiswaan (penanggung jawab), dosen dan wali kelas (pelaksana), mahasiswa (pendamping), siswa (peserta).

Material yang digunakan dalam program ini adalah modul, materi penyampaian tentang sampah (jenis, pengolahan, dan metode Takakura), selebaran, serta alat/bahan pengomposan dengan metode Takakura, selengkapnya tertuang di modul pelatihan. Program ini pada tahap pertama dilaksanakan sekitar 10 minggu pada rentang bulan Januari hingga Maret 2016, melibatkan 36 orang siswa di tiga SMA/MA yaitu SMAN 1 Aikmel, SMAN 2 Aikmel, dan MAN Wanasaba. Program ini dilaksanakan dalam tiga fase yang secara detail dipaparkan dalam tabel berikut:

Tabel 1. Alur pelaksanaan program sosialisasi dan pelatihan daur ulang sampah dengan metode Takakura

\begin{tabular}{|l|l|l|}
\hline \multicolumn{2}{|l|}{ Tahap Perencanaan dan Persiapan } & Kaprodi, \\
\hline Minggu ke & - Rapat penentuan lokasi dan waktu & Waka Kesiswaan, Wali kelas, \\
& - Pengurusan izin & Dosen, dan Mahasiswa \\
& - Koordinasi dengan pihak sekolah & \\
& Penyiapan materi sosialisasi (seminar), selebaran, dan & \\
& modul Takakura & \\
& - Pengadaan alat dan bahan & \\
\hline Tahap Implementasi & \\
\hline Minggu ke-4 & - Sosialisasi (seminar) & $\begin{array}{l}\text { Waka Kesiswaan, Wali Kelas, } \\
\text { Dosen, } \\
\text { dan Siswa }\end{array}$ \\
\hline
\end{tabular}




\begin{tabular}{|l|l|l|}
\hline Minggu ke-5 & $\begin{array}{l}\text { - Pelatihan daur ulang sampah dengan metode Takakura } \\
\text { - Praktik Mandiri di bawah pengawasan mahasiswa } \\
\text { pendamping } \\
\text { - Koordinasi dengan Waka. Kesiswaan dan Wali kelas } \\
\text { terkait pengontrolan setiap hari }\end{array}$ & $\begin{array}{l}\text { Dosen, Mahasiswa, Wali kelas, } \\
\text { dan siswa }\end{array}$ \\
\hline Tahap Monitoring & Dosen dan Waka. Kesiswaan \\
\hline Minggu ke-7 & Monitoring tahap 1 & Dosen dan Waka. Kesiswaan \\
\hline Minggu ke-9 & Monitoring tahap 2 & \\
\hline
\end{tabular}

\section{KAJIAN TEORITIK}

\section{a. Evaluasi Program}

Secara teoritis, pemahaman tentang evaluasi telah banyak diulas oleh para ahli, Grounlund dan Linn (2000: 5) mengemukakan bahwa evaluasi adalah proses yang sistematis dalam pengumpulan data, analisis data dan interpretasi informasi untuk menentukan tingkat pencapaian tujuan pengajaran. Djaali dan Mulyono (2000:1), menyatakan bahwa evaluasi sebagai proses menilai sesuatu berdasarkan kriteria atau tujuan yang telah ditetapkan, kemudian diambil keputusan atas obyek yang dievaluasi. Suchman dalam Arikunto (2010:1), mengungkapkan bahwa evaluasi adalah sebuah proses menentukan hasil yang telah dicapai beberapa kegiatan yang direncanakan untuk mendukung tercapainya tujuan. Sanjaya \& Divayana (2015:18) secara jelas menyatakan bahwa evaluasi adalah kegiatan untuk mengumpulkan data, analisis data dan penyajian data menjadi informasi tentang objek tertentu yang diteliti sehingga hasilnya dapat digunakan untuk mengambil keputusan. Dapat disimpulkan bahwa evaluasi merupakan kegiatan sistemik yang dilakukan untuk memperoleh dan menyajikan informasi atau data guna pengambilan keputusan berdasarkan kriteria yang diacu atau ditetapkan sebelumnya. Evaluasi juga diterapkan dalam dunia pendidikan. Salah satu bentuk evaluasi yang dikenal dalam kegiatan kependidikan adalah evaluasi program.

Evaluasi program pada hakikatnya merupakan proses mengumpulkan data yang berkenaan dengan kinerja seluruh komponen program, kualitas proses (perencanaan, implementasi, dan monitoring), dan mengukur tingkat pencapaian tujuan program yang dilaksanakan.

\section{b. Tujuan dan Manfaat Evaluasi Program}

Tujuan evaluasi program yang diharapkan dalam hal ini yaitu:

1. Memperoleh informasi tentang kualitas aplikasi program disetiap tahapannya

2. Mengumpulkan informasi tentang tingkat pemahaman dan kesadaran siswa tentang pentingnya mengolah sampah

3. Mendapatkan informasi tentang penguasaan keterampilan mengolah sampah dengan metode Takakura siswa

4. Mendapatkan informasi tentang kinerja stake holder dalam tiap tahap proses aplikasi program

Hasil dari evaluasi ini akan bermanfaat bagi para pengambil kebijakan, karena hasil evaluasi ini memberikan informasi menyeluruh mengenai aplikasi dari program ini, sehingga dapat dijadikan sebagai bahan pertimbangan untuk keberlanjutan serta perbaikan program ini di masa yang akan datang.

Kajian evaluasi program cukup bervariasi yang turut mempengaruhi jenis model evaluasi. Dari beberapa jenis, cara ataupun penyajian evaluasi program diidentifikasi bahwa semua bermuara pada penyediaan informasi dalam rangkaian pengambilan keputusan (decision) oleh decision maker. Menurut Arikunto dan Abdul Jabar (2010:22), ada empat kemungkinan kebijakan yang dapat dilakukan berdasarkan hasil evaluasi pelaksanaan program yaitu : 1) Menghentikan program, karena dipandang bahwa program tersebut tidak ada manfaatnya, atau tidak dapat terlaksana sebagaimana diharapkan. 2) Merevisi program, karena ada bagian-bagian yang kurang sesuai dengan harapan (terdapat kesalahan tetapi sedikit). 3) Melanjutkan program, karena 


\section{JURNAL KIPRAH, Juni 2018; V1(1): 25-34 \\ e-ISSN: 2580-6947 \\ p-ISSN: 2354-7278}

pelaksanaan program menunjukkan bahwa segala sesuatu sudah berjalan sesuai dengan harapan dan memberikan hasil yang bermanfaat. 4) Menyebarkan program (melaksanakan program ditempat lain atau mengulangi lagi program di lain waktu), karena program tersebut berhasil dengan baik, maka sangat baik jika dilaksanakan lagi di tempat dan waktu lain.

\section{c. Model CSE-UCLA (Alkins)}

Suchman dalam Arikunto (2010), mendefinisikan bahwa evaluasi merupakan proses menentukan hasil yang telah dicapai beberapa kegiatan yang direncanakan untuk mendukung tercapainya tujuan. Dengan kata lain, evaluasi merupakan suatu proses atau kegiatan pemilihan, pengumpulan, analisis dan penyajian informasi yang dapat digunakan sebagai dasar pengambilan keputusan serta penyusunan program selanjutnya (Andriani, 2015: 169).

Terdapat banyak model evaluasi program dalam dunia pendidikan, salah satunya adalah model CSE-UCLA (Center for the Study of Evaluation - University of California in Los Angeles). CSE-UCLA merupakan salah satu model atau desain yang digunakan dalam mengevaluasi suatu program pendidikan. Model CSE-UCLA merupakan model yang dikembangkan oleh Marvin Alkins (1969), dimana model ini juga sering disebut dengan istilah pendekatan sistem. Model CSE-UCLA terdiri dari lima tipe yaitu perencanaan, pengembangan, implementasi, hasil dan dampak. Nyre dan Rose dalam Andriani (2015) menyatakan keuntungan dari model CSE adalah bahwa hal ini berlaku untuk evaluasi diskrit, program instruksional yang didefinisikan dan sistem pendidikan dalam skala luas.

Model Alkinss menekankan proses evaluasi ditiap tahap aplikasi khususnya implementasi program. Evaluasi implementasi menjadi penting karena aplikasi rencana dan juga kinerja stake holder akan terlihat. Arnold Love mengemukakan salah satu metode untuk mengevaluasi tahap implementasi program ialah dengan evaluasi proses, yaitu mengukur seberapa baik pelayanan yang diberikan sesuai dengan yang direncanakan (Wholey, 2004: 67). Alkinss mendefinisikan evaluasi sebagai proses memastikan keputusan yang menjadi perhatian, menyeleksi informasi yang tepat, mengumpulkan dan menganalisis informasi dalam rangka untuk melaporkan data penting yang berguna bagi para pengambil keputusan dalam memilih antara berbagai alternatif keputusan yang akan diambil. Alkins mengemukakan lima tipe evaluasi dalam UCLA, yakni:

1. System Assesment, yaitu menyediakan informasi yang terkait posisi suatu program

2. Program Planning, menyediakan informasi tentang bagaimana program dipilih dan dirancang

3. Program Implementation, menyediakan informasi tentang pelaksanaan program pada kelompok sasaran yang tepat dan sesuai dengan yang diharapkan

4. Program Improvement, menyediakan informasi tentang bagaimana suatu program berfungsi, termasuk keberlanjutannya

5. Program Certification, menyediakan informasi tentang nilai dari suatu program dan kemungkinannya untuk dipergunakan lebih jauh.

Menurut Arikunto dan Cepi (2010: 22)., ada empat kemungkinan kebijakan yang dapat dilakukan berdasarkan hasil evaluasi pelaksanaan program yaitu: 1) Menghentikan program, karena dipandang bahwa program tersebut tidak ada manfaatnya, atau tidak dapat terlaksana sebagaimana diharapkan. 2) Merevisi program, karena ada bagian-bagian yang kurang sesuai dengan harapan (terdapat kesalahan tetapi sedikit). 3) Melanjutkan program, karena pelaksanaan program menunjukkan bahwa segala sesuatu sudah berjalan sesuai dengan harapan dan memberikan hasil yang bermanfaat. 4) Menyebarkan program (melaksanakan program ditempat lain atau mengulangi lagi program di lain waktu), karena program tersebut berhasil dengan baik, maka sangat baik jika dilaksanakan lagi di tempat dan waktu yang lain. 


\section{d. Model Tyler (Goal-Oriented Evaluation)}

Ralph W. Tyler adalah seorang pendidik Amerika yang bekerja dibidang penilaian dan evaluasi. Tyler menyebutkan bahwa penilaian pendidikan sebagai sebuah proses untuk menentukan sejauh mana tujuan-tujuan pendidikan dari program sekolah atau kurikulum tercapai. Evaluasi berorientasi program dari Tyler ini didesain untuk menggambarkan sejauh mana tujuan program telah dicapai. Tyler menggunakan kesenjangan antara apa yang diharapkan dan apa yang berhasil diamati untuk memberikan masukan terhadap kekurangan dari suatu program. Pendekatan ini memfokuskan pada tujuan spesifik dari program dan sejauh mana program ini telah berhasil mencapai tujuan tersebut. Hasil yang diperoleh dari evaluasi ini dapat dipakai untuk merumuskan kembali tujuan kegiatan, mendefinisikan ulang kegiatan/program, prosedur penilaian dan perangkat penilaian pencapaian tujuan.

Tyler mengemukakan dalam Fitzpatrick, Sanders, \& Worthen (2011: 155), bahwa evaluasi merupakan proses menentukan sejauh mana tujuan suatu program telah tercapai secara aktual. Tyler mengemukakan 7 langkah untuk menentukan sejauh mana tujuan suatu program telah dicapai yaitu : (1) menetapkan tujuan umum, (2) menggolongkan sasaran atau tujuan, (3) mendefinisikan tujuan dalam konteks perilaku, (4) menentukan situasi dimana pencapaian tujuan dapat terlihat, (5) mengembangkan atau memilih teknik pengukuran, (6) mengumpulkan data kinerja, (7) membandingkan data kinerja dengan perilaku yang menggambarkan tujuan.

\section{METODE}

Dalam studi kualitatif ini, penulis berupaya memunculkan sebuah konstruksi ilmiah baru dari beberapa model evaluasi program. Dalam hal ini penulis menggunakan studi kepustakaan (library research). Proses dalam studi ini dilaksanakan melalui penelaahan terhadap buku, literatur, dan artikel ilmiah tentang teori, karakteristik dan aplikasi dari model-model evaluasi program. Temuan dan hasil telaah pustaka yang didapatkan, selanjutnya dijadikan sebagai dasar untuk menyusun sebuah strategi evaluasi program yang sesuai dengan karakteristik program sosialisasi dan pelatihan pengolahan sampah dengan metode Takakura.

\section{HASIL DAN PEMBAHASAN}

Berangkat dari tujuan, manfaat, dan landasan teori yang disampaikan sebelumnya, maka untuk mengevaluasi program sosialisasi dan pelatihan ini peneliti menggunakan pendekatan alternatif yang mengkombinasikan antara decision oriented approaches dan program oriented approaches. Kombinasi ini disusun dengan melihat berbagai aspek yaitu karakteristik, fokus, kegunaan, dan keunggulan dari setiap pendekatan (Fitzpatrick, J.L., Sanders, J.R., \& Worthen, R.B)

Tabel 2: Detail aspek decision oriented dan program oriented approaches.

\begin{tabular}{|c|c|c|}
\hline . Aspek & Program-Oriented & Decision-Oriented \\
\hline $\begin{array}{l}\text { Focus of } \\
\text { Evaluation }\end{array}$ & $\begin{array}{l}\text { Menentukan ruang lingkup yang jadi } \\
\text { tujuan utama program, atau elemen kunci } \\
\text { dari konsep program yang telah } \\
\text { dihasilkan atau dicapai }\end{array}$ & $\begin{array}{l}\text { Menyiapkan informasi } \text { yang } \\
\text { bermanfaat untuk membantu } \\
\text { pengambilan keputusan }\end{array}$ \\
\hline $\begin{array}{l}\text { Distinguishing } \\
\text { Characteristics }\end{array}$ & $\begin{array}{l}\text { Fokus pada mengidentifikasi dan } \\
\text { menggambarkan elemen-elemen kunci } \\
\text { dari program dan mengapa elemen- } \\
\text { elemen itu harus bekerja; }\end{array}$ & $\begin{array}{l}\text { Membantu pembuatan keputusan yang } \\
\text { rasional; mengevaluasi setiap tahapan } \\
\text { dalam pengembangan program }\end{array}$ \\
\hline $\begin{array}{l}\text { Uses } \\
\text { (Past Uses) }\end{array}$ & $\begin{array}{l}\text { Perencanaan dan pengembangan } \\
\text { program; mengevaluasi hasil program } \\
\text { dan keterkaitannya dengan hasil program } \\
\text { tersebut }\end{array}$ & $\begin{array}{l}\text { Pengembangan program; sistem } \\
\text { organisasi managemen; perencanaan } \\
\text { program; akuntabilitas }\end{array}$ \\
\hline Strengths & $\begin{array}{llll}\text { Hubungan } & \text { yang } & \text { cepat pada pembuat } \\
\text { program } & \text { dan } & \text { literatur } & \text { penelitian; }\end{array}$ & $\begin{array}{l}\text { Komprehensif; sensitif untuk } \\
\text { kebutuhan informasi bagi pihak yang }\end{array}$ \\
\hline
\end{tabular}


JURNAL KIPRAH, Juni 2018; V1(1): 25-34

e-ISSN: 2580-6947

p-ISSN: 2354-7278

\begin{tabular}{|l|l|l|}
\hline memantu menjelaskan hasil program; & akan menggunakan hasil evaluasi; \\
mencegah adanya black box \\
(ketidaktahuan terhadap hasil); \\
mempertegas penjelasan terhadap hasil \\
program
\end{tabular} \mid

Dalam aplikasi praktis, evaluasi program ini memadukan dua model yaitu Tyler (goaloriented) dan Alkins (CSE-UCLA model). Dalam konteks evaluasi program ini, model Alkins digunakan untuk menentukan sasaran evaluasi program yang mencakup 3 komponen yaitu program planning, program implementation, program improvement. Sedangkan cara kerja untuk mendapatkan informasi mengenai sasaran tersebut menggunakan model Tyler yang terdiri atas 4 langkah, yakni define objectives, find situation, select and develop measurement technique, dan collect performance data.

\section{a. Logic Model Evaluasi Program \\ Sosialisasi dan Pelatihan Daur Ulang Sampah Dengan Metode Takakura}

Dalam konteks penilaian program, logic model dapat diartikan sebagai gambaran visual baik berupa skema atau yang lainnya, tentang pola kerja evaluasi didalam alur sistem program. Logic model evaluasi program ini disusun dengan mengacu pada struktur John McLaughlin dan Gretchen Jordan (Wholey, et al, 2004:8-9), dimana logic model setidaknya terdiri atas 5 komponen, yaitu: (1) resources; berupa manusia, finansial, dan lainnya yang ikut berperan dalam pencapaian tujuan program. (2) activities; langkah nyata untuk menghasilkan capaian program. (3) outputs; berupa produk, pelayanan, atau kebaikan yang diberikan secara langsung kepada peserta. (4) costumer; kelompok yang ikut menikmati hasil atau produk, (5) outcomes; perubahan yang dihasilkan dari kegiatan tersebut dan output. 


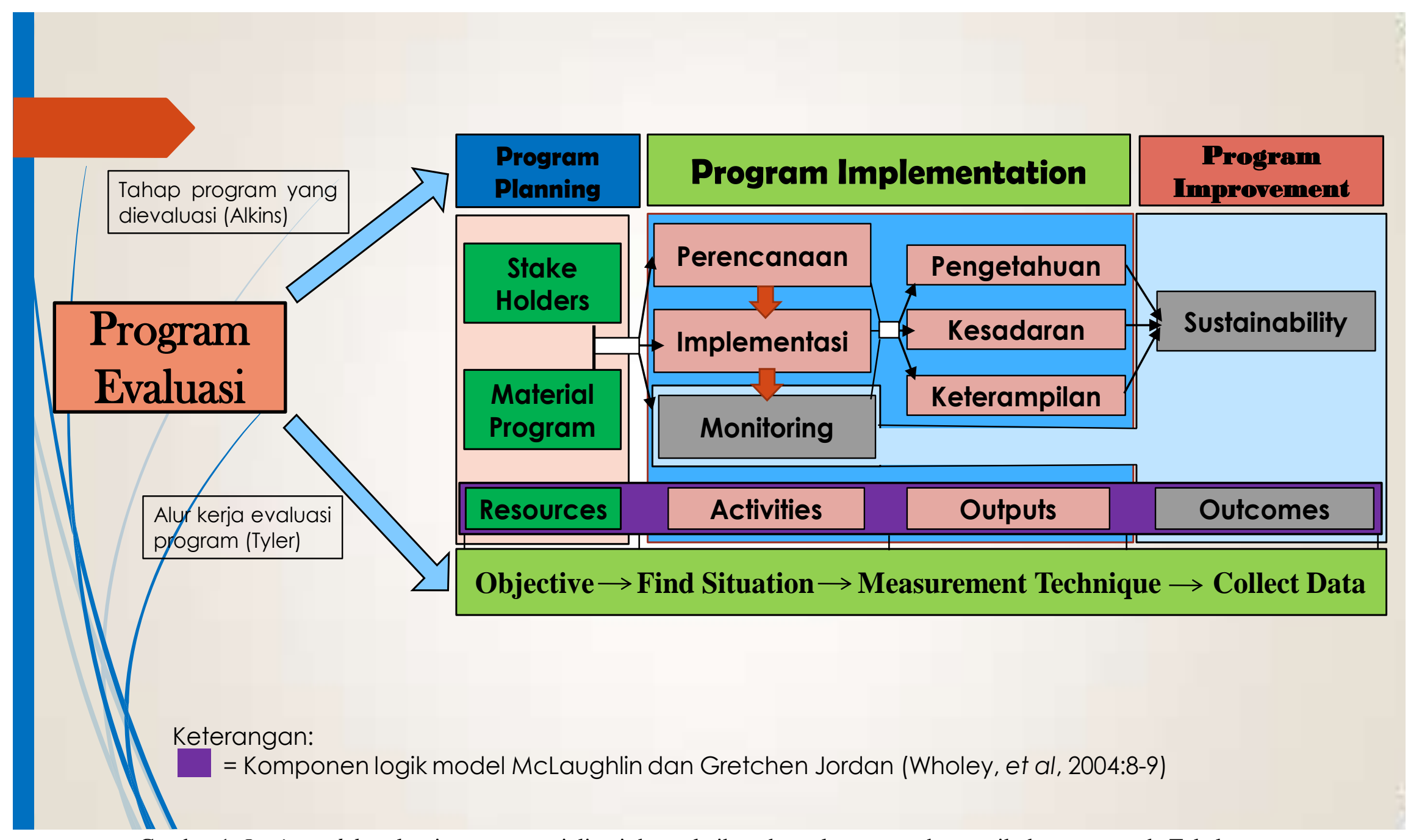

Gambar 1. Logic model evaluasi program sosialisasi dan pelatihan daur ulang sampah organik dengan metode Takakura 
JURNAL KIPRAH, Juni 2018; V1(1): 25-34

e-ISSN: 2580-6947

p-ISSN: 2354-7278

\section{b. Teknik dan Instrumen Pengumpulan Data Evaluasi}

Untuk mendapatkan informasi sesuai dengan kebutuhan tujuan

sumber, dan juga instrumen pengambilan data yang digunakan dalam

evaluasi

ini

dalam

tabel

dibawah

ini:

evaluasi, maka berikut kami sampaikan struktur, teknik pengambilan,

Tabel 3. Struktur data, teknik pengambilan, sumber data, dan instrumen pengambilan data

\begin{tabular}{|c|c|c|c|c|c|}
\hline No & Aspek & Informasi & $\begin{array}{c}\text { Teknik } \\
\text { Pengumpulan data } \\
\end{array}$ & Sumber Data & Instrumen \\
\hline \multicolumn{6}{|c|}{ Tahap Perencanaan dan Persiapan } \\
\hline & Persiapan & $\begin{array}{l}\text { - Penentuan sasaran, lokasi, dan waktu } \\
\text { - Koordinasi dengan pihak sekolah } \\
\text { - Penyiapan pendamping }\end{array}$ & $\begin{array}{l}\text { Review proposal } \\
\text { Interview }\end{array}$ & $\begin{array}{l}\text { - Tim Pelaksana } \\
\text { - Waka Kesiswaan } \\
\text { - Wali kelas } \\
\text { - Mahasiswa }\end{array}$ & $\begin{array}{l}\text { - Checklist } \\
\text { - Pedoman Wawancara }\end{array}$ \\
\hline & \multirow{2}{*}{$\begin{array}{l}\text { Material } \\
\text { (modul, } \\
\text { penyampaian, materi } \\
\text { selebaran, alat-bahan) }\end{array}$} & $\begin{array}{l}\text { - Kualitas keterbacaan, tampilan, dan konten } \\
\text { modul }\end{array}$ & $\begin{array}{l}\text { Review naskah } \\
\text { Kuisioner }\end{array}$ & $\begin{array}{l}\text { - Naskah Material Program } \\
\text { - Siswa }\end{array}$ & $\begin{array}{l}\text { - Checklist } \\
\text { - Angket } \\
\end{array}$ \\
\hline & & - Kualitas dan ketersediaan & Observasi & Material & - Lembar observasi \\
\hline \multicolumn{6}{|c|}{ Tahap Implementasi } \\
\hline & Seminar & $\begin{array}{l}\text { - Penyiapan tempat dan peserta } \\
\text { - Kualitas penyampaian materi }\end{array}$ & $\begin{array}{l}\text { Observasi } \\
\text { Kuisioner }\end{array}$ & $\begin{array}{l}\text { Ruangan } \\
\text { - Siswa }\end{array}$ & $\begin{array}{l}\text { - Lembar observasi } \\
\text { - Angket }\end{array}$ \\
\hline & Pendampingan & - Kinerja pendamping & Interview & - Siswa dan Dosen & - Pedoman Wawancara \\
\hline & Pelatihan & $\begin{array}{l}\text { - Kejelasan uraian dan mencontohkan } \\
\text { - Ketertiban (urutan) dalam penyampaian dan } \\
\text { mencontohkan tahapan proses Takakura } \\
\text { - Keterlibatan pendamping }\end{array}$ & $\begin{array}{l}\text { Kuisioner } \\
\text { Interview }\end{array}$ & - Siswa & $\begin{array}{l}\text { - Angket } \\
\text { - Pedoman Wawancara }\end{array}$ \\
\hline & Output & $\begin{array}{l}\text { - Pengetahuan tentang sampah dan Takakura } \\
\text { - Kesadaran daur ulang sampah } \\
\text { - Keterampilan mendaur ulang sampah dengan } \\
\text { metode takakura }\end{array}$ & $\begin{array}{l}\text { Tes } \\
\text { Kuisioner } \\
\text { Observasi }\end{array}$ & - Siswa & $\begin{array}{l}\text { - Tes } \\
\text { - Angket } \\
\text { - Lembar observasi }\end{array}$ \\
\hline \multicolumn{6}{|c|}{ Tahap Monitoring } \\
\hline & Kinerja pendamping & $\begin{array}{l}\text { - Intensitas kedatangan } \\
\text { - Koordinasi dengan sekolah } \\
\text { - Substansi monitoring } \\
\text { - Intensitas dan kualitas interaksi dengan siswa }\end{array}$ & $\begin{array}{l}\text { Review data tamu } \\
\text { sekolah } \\
\text { Interview }\end{array}$ & $\begin{array}{l}\text { Buku tamu } \\
\text { Waka Kesiswaan } \\
\text { Wali kelas } \\
\text { Siswa }\end{array}$ & $\begin{array}{l}\text { - Checklist } \\
\text { - Pedoman Wawancara }\end{array}$ \\
\hline
\end{tabular}




\section{c. Teknik Analisis Data Evaluasi}

Data yang diperoleh dalam kegiatan evaluasi ini pertama-tama akan diklasifikasikan sesuai jenisnya yaitu data kualitatif dan data kuantitatif. Secara kualitatif, data akan ditranskripsi, dipilih dan disusun tersebut untuk memperoleh/mendapatkan general sense dan merefleksikan maknanya secara keseluruhan, ada triangulasi dengan data dari sumber berbeda, dan diinterpretasi. Secara kuantitatif, pertama dilakukan konversi data dari ordinal ke interval dengan mengacu pada kriteria dari Sukardjo (2005) sebagai berikut :

Tabel 4. Konversi data kuantitatif ke kualitatif dengan skala lima

\begin{tabular}{|c|l|c|}
\hline Nilai & \multicolumn{1}{|c|}{ Interval Skor } & Kategori \\
\hline A & $X>\bar{X}_{i}+1,80 S B_{i}$ & Sangat Baik \\
\hline B & $\bar{X}_{i}+0,60 \bar{X}_{i}<X \leq \bar{X}_{i}+1,80 S B_{i}$ & Baik \\
\hline C & $\bar{X}_{\bar{i}}-0,60 S B_{i}<X \leq \bar{X}_{i}+0,60 S B_{i}$ & Cukup \\
\hline D & $\bar{X}_{i}-1,80 S B_{i}<X \leq \bar{X}_{i}-0,60 S B_{i}$ & Kurang \\
\hline E & $X \leq \bar{X}_{i}-1,80 S B_{i}$ & Sangat \\
& & Kurang \\
\hline
\end{tabular}

Keterangan:

$\bar{X}_{\bar{i}}=$ Rerata skor ideal $=1 / 2$ (skor maksimal ideal+ skor minimal ideal $)$.

$S B_{i}=$ Simpangan baku ideal $=1 / 6$ (skor maksimal ideal - skor minimal ideal).

$\mathrm{X}=$ Skor Aktual 
JURNAL KIPRAH, Juni 2018; V1(1): 25-34

e-ISSN: 2580-6947

p-ISSN: 2354-7278

Selanjutnya bersama data kualitatif, kemudian akan dilakukan interpretasi dan perumusan menjadi sebuah kesimpulan, yang selanjutnya diturunkan menjadi rekomendasi.

\section{KESIMPULAN}

Strategi evaluasi yang baik tentu akan membuat program sosialisasi dan pelatihan daur ulang sampah dengan metode Takakura menjadi semakin baik. Evaluasi dengan pendekatan alternatif (kombinasi antara decision oriented approaches dan program oriented approaches) dengan perpaduan dua model yaitu Tyler (goal-oriented) dan Alkins (CSE-UCLA model) adalah pilihan yang sesuai untuk melakukan evaluasi terhadap program ini. Kedua model tersebut bisa saling melengkapi satu dengan yang lainnya, dimana model Alkins digunakan untuk menentukan sasaran evaluasi program sementara model Tyler menyiapkan cara kerja mendapatkan informasi mengenai sasaran tersebut. Pendekatan alternatif yang ditawarkan dalam evaluasi program ini akan memberikan informasi yang utuh mengenai seluruh komponen program, sehingga dapat dijadikan sebagai bahan pertimbangan bagi pengambil kebijakan (Science Club) untuk proses aplikasi program dimasa yang akan datang. Dalam konteks sekolah adiwiyata, pendekatan alternatif untuk evaluasi program daur ulang sampah dengan metode Takakura ini dapat dimanfaatkan oleh pihak sekolah untuk menilai kualitas serta menentukan keberlanjutan program tersebut dalam menunjang pencapaian sekolah adiwiyata.

\section{REFERENSI}

Arikunto, S., \& Cepi, S. (2010). Evaluasi Program Pendidikan; Pedoman Teoritis-Praktis Bagi Mahasiswa Dan Praktisi Pendidikan. Jakarta : Bumi Aksara

Djaali dan Puji Mulyono, (2000). Pengukuran dalam Bidang Pendidikan. Jakarta: PPs UNJ
Fitzpatrick, J.L., Sanders, J.R., \& Worthen, R.B. (2011) Program Evaluation: Alternative Approaches and Practical Guidelines. New Jersey: Pearson Education Inc.

Gall, Meredith D., Joice P. Gall dan Walter R. Borg. (2003). Educational Research An Introduction. Boston: Pearson Education Inc.

Gronlund, Noman E. dan Robert L. Linn, (2000). Measurement and Evaluation in Teaching. New York: McMilan Publishing Co.

Joseph S. Wholey, Harry P. Hatry, Kathryn E. Newcomer. (2004). Handbook of Practical Program Evaluation, $2^{\text {nd }}$ ed. San Fransisco: John Wiley \& Sons, Inc.

Sanjaya, D.B., \& Divayana, D.G.H. (2015). An Expert System-Based Evaluation of Civics Education as a Means of Character Education Based on Local Culture in the Universities in Buleleng. International Journal of Advanced Research in Artificial Intelligence, Vol. 4, No.12: 17-21.

Siska Andriani. (2015) Evaluasi CSE-UCLA pada Studi Proses Pembelajaran Matematika. Jurnal Al-Jabar; Jurnal Pendidikan Matematika, Vol. 6, No.2: $167-175$ 
Amin: Pendekatan Alternatif Sebagai ... (3) 